\title{
The thoracoabdominal saga and heroes
}

\author{
Lars G. Svensson, MD, PhD
}

\author{
From the Heart and Vascular Institute, Cleveland Clinic, Cleveland, Ohio. \\ Funding provided by Cleveland Clinic and the Marty and Michelle Weinberg and Family Fund. \\ Disclosures: Author has nothing to disclose with regard to commercial support. \\ Received for publication Sept 7, 2017; accepted for publication Sept 13, 2017; available ahead of print Oct 10 , \\ 2017. \\ Address for reprints: Lars G. Svensson, MD, PhD, Chairman, Heart and Vascular Institute, Cleveland Clinic, 9500 \\ Euclid Ave/Mail Stop J1-227, Cleveland, OH 44195 (E-mail: svenssl@ccf.org). \\ J Thorac Cardiovasc Surg 2018;155:459-60 \\ $0022-5223 / \$ 36.00$ \\ Copyright (C) 2017 by The American Association for Thoracic Surgery \\ https://doi.org/10.1016/j.jtcvs.2017.09.053
}

Sagas are ancient Norse or Icelandic stories, passed down through oral tradition, written narratives, or poetry, that herald the heroic exploits or battles waged by Viking leaders, men and women alike. One saga details sailing around the elbow of Cape Cod and then into protected bays to trade with the local Native-American community, while another tells of a Viking woman who saved her crew off Canada and returned to Iceland.

Now, in an interesting parallel, the renowned thoracoabdominal surgical exploits of Michael DeBakey and E. Stanley Crawford are hailed in present-day cardiovascular sagas passed on by those who knew these "legerdemain" surgeons at Baylor College of Medicine, apart from their written reports of exemplary surgical prowess. ${ }^{1-3}$ In this issue of the Journal, Joseph S. Coselli and his team ${ }^{4}$ further the legacy of the remarkable surgeons of Baylor College as they report tackling tough aortic thoracoabdominal operations, including complex reoperations. The latter are not operations for young tyros.

Reoperations for thoracoabdominal disease are required for several reasons, including extension of the disease beyond the previous repair, usually into the abdomen or aortic arch; aneurysmal enlargement of the Carrel patches, either at intercostal/lumbar artery reimplantation or the visceral patch, particularly in patients with connective tissue disorder; or failed endovascular attempted repairs. In this remarkable series of 726 aortic reoperations, 146 patients $(20 \%)$ previously had proximal ascending or aortic arch operations, $176(24 \%)$ descending thoracic aortic repairs, $149(20 \%)$ thoracoabdominal repairs, and 469 $(65 \%)$ abdominal aortic repairs. ${ }^{4}$ With the exception of previous proximal or endovascular repairs, thoracoabdominal reoperations, by necessity, entail cutting through extensive scar tissue and freeing the lung, except in patients undergoing circulatory arrest. This alone requires not only patience but meticulous technique to avoid damaging adjacent organs, including the left lung, spleen, heart, recurrent nerve, bowels, or the aneurysm itself. Indeed, an early misadventure can result in tremendous blood and blood product loss, up to 400 units, as described in a saga about

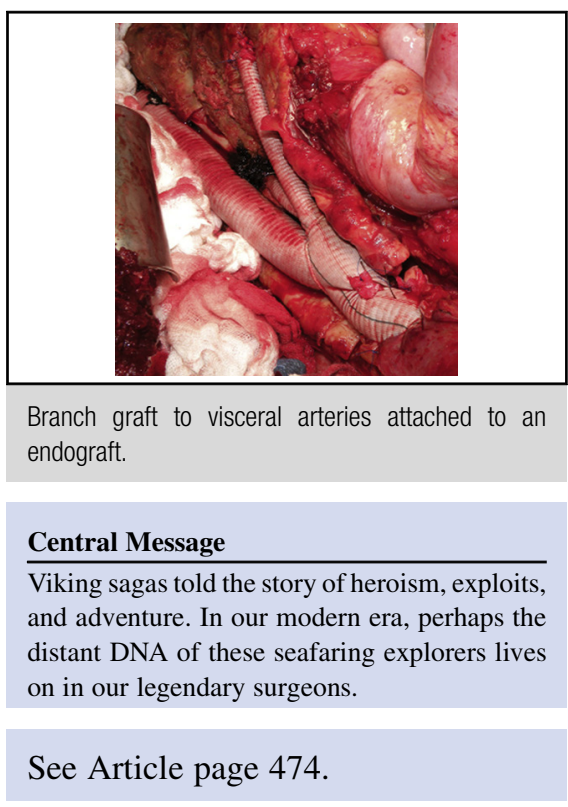

Dr Crawford. Once everything is mobilized and prepared for the actual repair, the technique is similar to that of a primary case, with 2 particularly important exceptions. For Carrel-patch aneurysms, branched grafts must be performed to the individual arteries, as we frequently do for primary operations on patients with connective tissue disorders (Figure 1, $A$ ). For patients with endografts, we usually transect the aorta and sew to both the transected aorta and the endograft stump (Figure 1, B).

As with all thoracoabdominal aortic repairs, spinal cord protection, renal protection, stroke prevention, and reducing cardiac impedance afterloading are paramount. My preference is to perform cerebrospinal fluid drainage with infusion of intrathecal papaverine, which we have shown significantly reduces the risk of paralysis, combined with moderate cooling on atriofemoral bypass and cold fluid renal infusion. ${ }^{5}$ The Coselli team also has demonstrated the benefit of cerebrospinal fluid drainage and cold fluid or blood renal infusion in a prospective randomized trial. ${ }^{4}$

Given the vagaries, skill, and heroics required for reoperative thoracoabdominal surgery, the saga achieved by the Coselli group is extraordinary, considering their total of 726 reoperations out of 3379 thoracoabdominal repairs. Furthermore, to achieve such low mortality and paralysis-no different than for primary repairs-is a steep coastal beachhead cliff that many aspire to scale yet few surmount.

Do Dr Coselli's Italian forefathers reference the Vikings in their own sagas of heroism? Indeed they do. In Dante's 

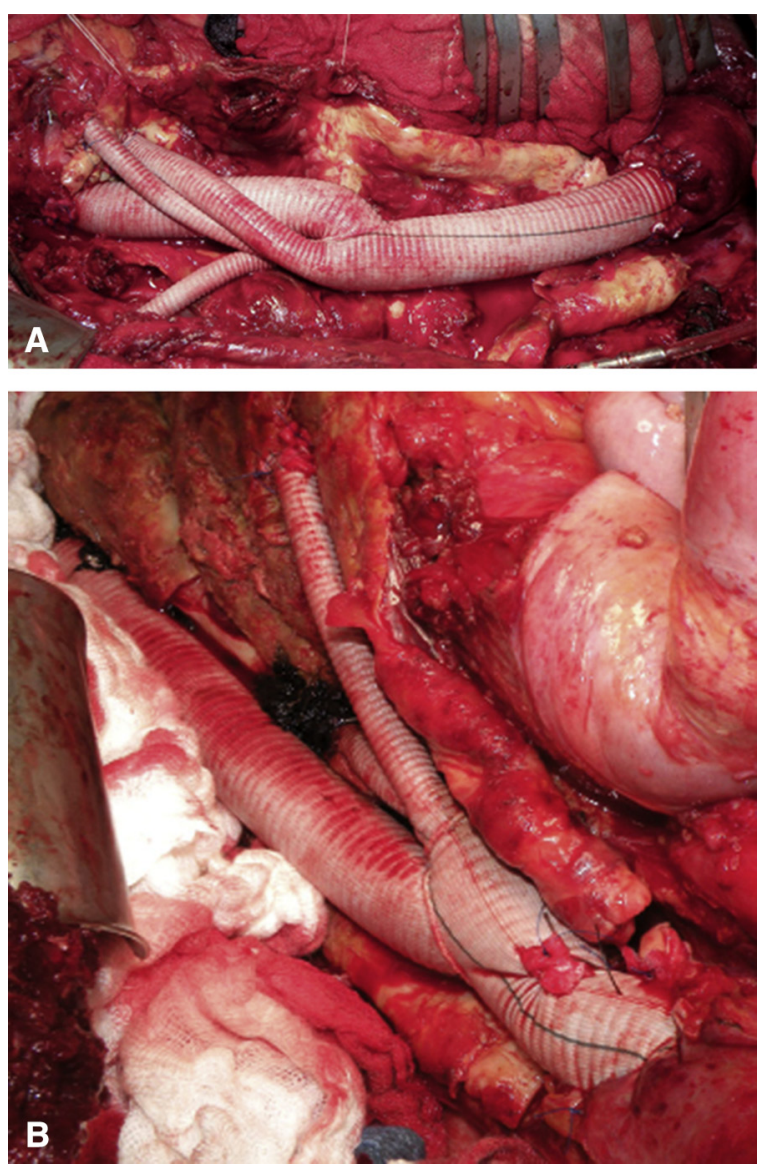

FIGURE 1. Examples of branch grafts to visceral arteries. A, Standard method. B, Graft sewn to stump of an endograft.

Inferno, he references a Viking chieftain and his family who controlled the southern half of Italy and Sicily for 70 years.
Furthermore, DNA Y-chromosome analysis shows a high concentration of Viking genes in southern Italy and Sicily. These Viking Y-chromosomes are among the most widespread genes in males from Western Europe, particularly in areas in which Vikings conquered the coastline, settled, and lived. Perhaps the epic tales of the Vikings have evolved into unrecorded sagas of many modern, unsung heroic surgeons taking on the most formidable of operations for the betterment of their patients. Similar sagas of seafaring courage can be found in Chinese (Zheng He), Indian (Komati Davidian), Phoenician, and other ancient histories.

That genetic distant glimmer of adventure, boldness, and heroism continues in all surgeons who take on these complex operations. Patients and their families often are unaware of the medical realities of these surgical cases and do not realize surgeons' personal sacrifices. We should applaud their achievements as true sagas of modern-day heroism.

\section{References}

1. DeBakey ME, Creech O Jr, Morris GC Jr. Aneurysm of thoracoabdominal aorta involving the celiac, superior mesenteric, and renal arteries; report of four cases treated by resection and homograft replacement. Ann Surg. 1956;144:549-73.

2. Crawford ES, Crawford JL, Safi HJ, Coselli JS, Hess KR, Brooks B, et al. Thoracoabdominal aortic aneurysms: preoperative and intraoperative factors determining immediate and long-term results of operations in 605 patients. J Vasc Surg. 1986;3:389-404.

3. Svensson LG, Crawford ES, Hess KR, Coselli JS, Safi HJ. Experience with 1509 patients undergoing thoracoabdominal aortic operations. J Vasc Surg. 1993;17: 357-68; discussion 368-0.

4. Coselli JS, Rosu C, Amarasekara HS, Green SY, Zhang Q, Price MD, et al. Reoperative surgery on the thoracoabdominal aorta. J Thorac Cardiovasc Surg. 2018; $155: 475-85$.

5. Lima B, Nowicki ER, Blackstone EH, Williams SJ, Roselli EE, Sabik JF III, et al. Spinal cord protective strategies during descending and thoracoabdominal aortic aneurysm repair in the modern era: the role of intrathecal papaverine. $J$ Thorac Cardiovasc Surg. 2012;143:945-52. 